\title{
Transaction Avoidance in Bankruptcy of Corporate Groups
}

\author{
by
}

IrIT MeVORACH*

The complex business structure of corporate groups has many legislative challenges. One such issue is the operation of avoidance provisions in the bankruptcy context. The paper investigates this matter focusing on the recent recommendations made by UNCITRAL in this area. The paper unearths the underlying principles of the new proposals against the backdrop of the "entity law" versus "enterprise law" debate (regarding groups regulation) and the general goals of bankruptcy laws, as well as considers the extent to which these proposals are desirable. The paper also discusses the relationship between avoidance provisions and other solutions for the bankruptcy of groups and the problems which arise where multiple jurisdictions are affected by voidable transactions.

Table of Content $\quad$ ECFR 2011, 235-258

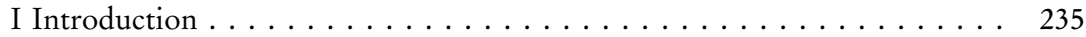

II Typical Avoidance Provisions . . . . . . . . . . . . . . . . . . . . . 239

III Addressing the Group Problem . . . . . . . . . . . . . . . . . 243

A. Legal Form Versus Economic Realities . . . . . . . . . . . . . . . . . 243

B. Adjusting the Usual Avoiding Provisions to Accommodate Corporate Groups .......................... 245

C. Avoidance Provisions versus Other Solutions for Group Bankruptcies . 250

IV A Comment on International Complexities . . . . . . . . . . . . . . . . 254

V Conclusion . . . . . . . . . . . . . . . . . . . . . . 257

\section{Introduction}

While the concept of avoiding transactions which harm creditors can be dated back to Roman times, ${ }^{1}$ corporate groups are a much more recent phenomen-

* Associate Professor, School of Law, University of Nottingham; Ph.D., University College London; L.L.M., L.L.B., Tel-Aviv University. The article is based on a paper presented at the $5^{\text {th }}$ ECFR Symposium. I am grateful for the helpful comments of colleagues in attendance at the conference. I would also like to thank the British Academy for funding parts of the research on which this article is based.

1 The Paulian Action (action Pauliana) regarding transactions in fraud of creditors is derived from Roman law. 
on. ${ }^{2}$ Perhaps this is why the application of transaction avoidance provisions in the context of groups' bankruptcies ${ }^{3}$ is not trivial.

Avoidance provisions can promote a fair and efficient insolvency system - one which treats stakeholders equitably, ${ }^{4}$ minimises costs inherent to bankruptcy and maximises wealth. Such provisions address misbehaviour of managers near default, ensuring that creditors as a whole are treated equitably by allowing payments made or property transferred under certain transactions to be returned to the company or their effect reversed. In doing so, the law takes into account the diversity of creditors' types and the different positions of the relevant stakeholders vis-a-vis the company. ${ }^{5}$ It appreciates that the managers are in a position to divert assets to themselves or to connected persons, acting near default. ${ }^{6}$ Among the creditors, some may be 'mal-adjusting', i.e. in a weak position, and may have little or no opportunity to calculate such risks, ${ }^{7}$ while others may be able to pressurise the company and make it favour them. ${ }^{8}$ If transactions conducted for the purpose of benefiting the company are not attacked but only those which have worsened the company's position, a proper balance is struck between the need to ensure the ultimacy of the transaction, certainty and stability and the need to remedy the harm caused to creditors. Otherwise, fraud should always be combated and dishonest transactions should be attacked. ${ }^{9}$ The adjustment of transactions further preserves collec-

2 It appears that corporate groups first surfaced in the US at the end of the $19^{\text {th }}$ century (see on the emergence of corporate groups PI Blumberg The Multinational Challenge to Corporation Law: the search for a new corporate personality (Oxford University Press, Oxford 1993) [hereinafter: Blumberg, The Multinational Challenge]).

3 The article uses the terms "bankruptcy" and "insolvency" interchangeably.

4 By according equal respect and consideration to all relevant interested parties in the choice of insolvency law principles (see R Dworkin, Sovereign Virtue: The Theory and Practice of Equality (2000), 11; R Dworkin, “The Original Position” in Reading Rawls: Critical Studies on Rawls' “A Theory of Justice” (Norman Daniels, ed. 1989), 50).

5 A fair distribution between creditors requires taking into account their relative bargaining power and vulnerability in regard to their ability to respond to bankruptcy risks ex ante and their ability to bear bankruptcy loss ex post (see e.g. E Warren "Bankruptcy Policy” (1987) 54 Univ. of Chicago Law Rev. 775, 778).

6 RJ Mokal, Corporate Insolvency Law: Theory and Application (Oxford University Press, Oxford 2005) [hereinafter: Mokal, Corporate Insolvency], 308.

7 I.M. Ramsay, Models of Corporate Regulation: The Mandatory/Enabling Debate in R. Grantham and C. Rickett (eds), Corporate Personality in the 20th Century 215, 253 (1998), 256; V. Brudney, Corporate Bondholders and Debtor Opportunism: In Bad Times and Good 105 Harv. L. Rev. 1821 (1992).

8 Mokal, Corporate Insolvency (supra note 6) 309.

9 See D.G. Baird, "Legal Approaches to Restricting Distribution to Shareholders: The Role of Fraudulent Transfer Law" (2006) EBOR 7, 199 [hereinafter: Baird, Legal Approaches]. 
tivity in insolvency (avoiding the "common pool" problem ${ }^{10}$ ) and ensures value is not destroyed by removing assets from the estate. In particular, rescue attempts may be undermined where the company is deprived of assets which are essential for its ongoing activity. ${ }^{11}$ Thus, reversing vulnerable transactions can enlarge the insolvency estate and increase returns to creditors. ${ }^{12}$

This is also recognised internationally. Proclamations of broadly accepted insolvency objectives provided in the United Nations Commission on International Trade Law (UNCITRAL) Insolvency Guide ("the Insolvency Guide") ${ }^{13}$ suggest that creditors should be treated equitably. ${ }^{14}$ This, it is suggested, requires addressing problems of fraud and favouritism that may arise in cases of financial distress by providing, for example, that acts and transactions detrimental to equitable treatment of creditors can be avoided. ${ }^{15}$ The Insolvency Guide also stresses the goal of maximising the value of the estate, ${ }^{16}$ in particular by imposing a collective process and stopping the race to collect. ${ }^{17} \mathrm{It}$ furthermore states that the insolvency law should allow for the possibility of reorganisation where the value of the debtor to society and to creditors may be maximised by allowing it to continue its business activities. ${ }^{18}$

The phenomenon of corporate groups - comprised as they are of separate but linked entities ${ }^{19}$ - challenges the operation of transaction adjustments in bankruptcy. Managers may not only consider the situation of the particular com-

10 Created when diverse 'co-owners' assert rights against a common pool of assets (see T.H. Jackson "Bankruptcy, nonbankruptcy and the creditors' bargain” (1982) 91 Yale L.J. 857).

11 Synergetic values created by the presence of the appropriate combinations of productive assets within the estate may be destroyed (see Mokal, Corporate Insolvency (supra note 6), 310).

12 Though, consideration should also be given to the potential cost of litigation and the likelihood of success of the attempt to tackle a transaction.

13 See UNCITRAL Legislative Guide (U.N. Comm'n on Int'l Trade Law [UNCITRAL] Legislative Guide on Insolvency Law 2004.

14 Ibid., Part One, Ch. I (B), Para. 10 (Objective 6).

15 Ibid., Para. 7 (Objective 4). See also ibid., Part two, Ch. II, Para. 151.

16 Ibid, Para. 5 (Objective 2).

17 See also I. F. Fletcher, Insolvency in Private International Law (Oxford University Press, Oxford 2005, supplement 2007) [hereinafter: Fletcher, Insolvency], 9 (observing that the concept of collectivity is shared among legal systems).

18 The Insolvency Guide (supra note 13), Part one, Ch. 1 (B), Para. 6 (Objective 3).

19 The question of the nature of the links between entities and what makes them a group is a question not uniformly answered in different regimes, but in a recent addition to the Insolvency Guide, it is suggested that an enterprise group will be defined as: "two or more enterprises that are interconnected by control or significant ownership." (a prerelease (21 July 2010) of the new Part (Part III) is available at: <http://www.uncitral.org/ pdf/english/texts/insolven/pre-leg-guide-part-three.pdf $>$ [accessed: May 2011] [hereinafter: Part III of the Guide], Glossary 4(a)). 
pany when they enter into such transactions, but possibly also that of other affiliates; favoured creditors may be affiliated companies; transactions may include cross-guarantees and loans to different parts of the group; they may also present themselves in massive amounts where intra-group transactions were the routine; and the entry into transactions may range from fraud to negligence to implementing a group policy designed to save the group. ${ }^{20}$ Bearing in mind these varying circumstances and special relationship between group members, the general rules on voidable transactions may not give sufficient solutions in the group context. The question is how the voidable transactions provisions may be adjusted to accommodate the group phenomenon, and whether other remedies for groups in bankruptcy may be more appropriate for combating fraudulent and other suspect transactions under certain circumstances.

This issue is timely and significant, not only because the phenomenon of groups is now prominent in global commerce ${ }^{21}$ and the global financial crisis highlighted the need for immediate solutions to meet the challenges of largescale defaults, ${ }^{22}$ but also because the matter of groups in bankruptcy (including the treatment of vulnerable transactions) has been recently discussed on the international level (by an UNCITRAL working group) and a set of international standards has been proposed..$^{23}$ Obviously, the success of these recent endeavours depends on their wide implementation by national regimes. ${ }^{24}$ It is

20 See further infra Part IV.

21 I. Mevorach, Insolvency within Multinational Enterprise Groups (Oxford University Press, 2009), 33 [hereinafter: Mevorach, Enterprise Groups].

22 See e.g. alleged intra-group transfers which took place prior to the collapse of Lehman Brothers banking group (S. Tucker, Lehman's Asia Risk is Revealed, November 262008. Financial Times; V. Heany Winding Up Lehman, Accountancy (2008) 142 (1383) 94), and alleged fraud regarding intra-group claims between Parmalat subsidiaries (see "Parmalat ask Kroll to find assets", Financial Times, March 2, 2004; D Reilly "Judge Rejects Administrator's Push To Control Parmalat's Cayman Units”, DOWJONES Newsletters, International Insolvency, March 2, 2004, p. 1, 3)

23 On which see infra Part III.B.2. The proposals of Working Group V (the working group of UNCITRAL which deals with insolvency matters) will be added to the Insolvency Guide as Part III (see Part III of the Guide, n 19). I had the privilege of serving as an adviser to the UK delegation in the deliberation of the Working Group, yet the views expressed in this study in regard to the work of UNCITRAL are, of course, my own views and do not necessarily reflect those of the UK delegation or of the Working Group. There are also interesting developments within the EU regarding cross-border banking groups in crises, yet the peculiar case of banks and other financial institutions is outside the scope of this paper (see R. Nattrass, "Cross-border intra-group asset transfers: too big to ignore?" 5 JIBFL (2010) on these developments).

24 S. Block-Lieb and T. Halliday "Harmonization and Modernization in UNCITRAL Legislative Guide on Insolvency Law” (2007) 42 Tex. Int'l L. J. 475, 511 [hereinafter: Block-Lieb and Halliday, Harmonization] (noting that in order to assess the harmoni- 
therefore crucial to unearth the underlying principles of the proposals at this stage and appreciate the extent to which they are desirable (and should thus be considered favourably by policy makers). This is the task this article sets forth to undertake. The article also examines the relationship between the proposals and other solutions for groups in bankruptcy discussed by UNCITRAL, and briefly addresses the complexities arising when transactions (involving group members) affect multiple legal regimes.

The paper proceeds as follows. Part II provides a brief overview of avoidance provisions available in different legal regimes, taking both a comparative and an international perspective. Thus, common denominators are highlighted as well as international standards proposed in this area "from the top". Part III discusses the group problem. It first introduces the basic dilemma in the treatment of groups in general, i.e. the tension between entity law and enterprise principles and the legitimising arguments of each approach. In this light, different problems associated with groups should be resolved. Against this background, the recommendations of UNCITRAL regarding avoidance provisions in the group context are then analysed, as well as the relationship between avoidance provisions and other solutions for group insolvencies. Part IV comments on the international complexities, and Part V concludes.

\section{Typical Avoidance Provisions}

Transactions avoidance provisions are found in many bankruptcy laws. ${ }^{25}$ Although there are variations in the details of these provisions, ${ }^{26}$ they are based on some common objectives, ${ }^{27}$ and have some significant similarities. As the paper seeks to demonstrate the desirability of some adjustments to avoidance provisions in the context of corporate groups, which should be considered across nations, it is important to firstly highlight such agreements between legal regimes regarding the basic elements of avoiding powers before discussing the group problem. This section will, therefore, delineate the typical avoidance provisions found in legal regimes, stressing the similarities between

sation effect of the Guide we will need to study the legislation the Guide has inspired and the implementation of that legislation by courts, insolvency representatives and insolvency professionals).

25 J.L. Westbrook 'Locating the Eye of the Financial Storm' (2007) 32 Brook J Int'l L 1019, 1021; Fletcher, Insolvency (supra note 17), 400; J.L. Westbrook, “Avoidance of PreBankruptcy Transactions in Multinational Bankruptcy Cases” (2007) 42 Tex. Int'l L. J. 899, 901-02 [hereinafter: Westbrook, Avoidance]). See also the Insolvency Guide (supra note 13), Part Two, Ch. II, Para. 150.

26 Ibid.

27 Those objectives were delineated above (see supra notes 14-18 and accompanying texts). 
them (i.e. the usual powers and typical criteria attached to them), ${ }^{28}$ as well as refer to the international standards of avoidance provisions (already agreed upon in the original Insolvency Guide). ${ }^{29}$

The Insolvency Guide mentions three types of avoidable transactions that are found in most legal systems: transactions intended to defeat, hinder or delay creditors from collecting their claims; transactions at an undervalue; and transactions with certain creditors that have the effect of preferring them over all other creditors. ${ }^{30}$ Each of these avoidable transactions has some specific characteristics, depending on the circumstances of the transaction. They may have characteristics of more than one power to avoid, and thus the insolvency representative may be able to choose on which basis to challenge it. ${ }^{31}$

Avoiding powers related to transactions defrauding creditors are the most ancient - as aforementioned, they find their origins in the actio Pauliana of Roman law. For the challenge of a transaction as fraudulent it is usually required to prove intent of the debtor, normally by identifying circumstances or indicators that are common to this type of transaction, such as the relationship between the parties involved in the transaction, the fact that the transaction was concealed and so forth. ${ }^{32} \mathrm{It}$ is also quite usual that transactions that involve intentionally wrongful conduct are regarded avoidable either without any reference to a specific suspect period (i.e. such transactions can be avoided even if entered into in the ordinary course of the company's business and not in the vicinity of insolvency) or with reference to a very long time limit. ${ }^{33}$ This suits the goal of combating fraud - dishonest behaviour should never be encouraged. ${ }^{34}$

Undervalued transactions would generally be avoidable where the value received by the debtor company as the result of the transaction was either merely nominal or non-existent, e.g. when the company made a gift, or where the

28 This will be mainly based on the commentary on avoidance provisions in different legal regimes provided in the Insolvency Guide (Insolvency Guide (supra note 13), Part Two, Ch. II, Paras. 148-202).

29 Provided in the Insolvency Guide (ibid., recommendations 87-99).

30 Ibid, Part two, Para. 170.

31 Ibid.

32 Ibid, Para. 172. Yet, there may be differences regarding the level of proof required to establish intent to defraud. Most notably, in 'haven' jurisdictions (specialising in offshore trusts) it is usual to require proof beyond reasonable doubt that the debtor had intent to defraud (see R. Perry, "Transaction Avoidance Provisions in International Insolvencies”, (2004) ICCLR 46, 48 [hereinafter: Perry, Transaction Avoidance]).

33 Ibid., Para. 189. For example, ss. 423-425 of the English Insolvency Act 1986 dealing with transactions defrauding creditors do not specify any time limit within which such transactions will be regarded as suspect.

34 Supra note 9 and accompanying text. 
amount it had received as consideration was significantly lower than the true value or market price. This is provided the transaction occurred within a suspect period, i.e. within some (pre-defined) period prior to the commencement of or application for insolvency proceedings. The law may provide defences so that the transaction is not avoided if certain conditions are satisfied such as that the beneficiary acted in good faith, the transaction was entered into for the purpose of carrying on the debtor business and that there were reasonable grounds to believe that the transaction would benefit the debtor's business. ${ }^{35}$ The idea is to restrict the application of the power to avoid to the vicinity of insolvency and to circumstances where the transaction was clearly harmful to the creditors as a whole. ${ }^{36}$ Identifying a transaction as undervalued for this purpose may not be a simple task. ${ }^{37}$ Yet, it seems that substance should win over form and the transaction should be investigated in its totality, enquiring whether the transaction was undervalued as a matter of economic reality in the sense delineated above. ${ }^{38}$

Preferences are normally subject to avoidance if they took place within a suspect period, involved a transfer to a creditor on account of an antecedent debt and as a result of the transaction the creditor received a larger percentage of its claim than other creditors. Another typical requirement is that the debtor was insolvent or close to insolvency when the transaction took place; some laws further require the intent to prefer. ${ }^{39}$ Normally, there are defences available, for example when it can be shown that the transaction was consistent with normal commercial practise between the parties, or that new value was created. ${ }^{40}$ The idea is to treat creditors equitably and tackle favouritism, yet not to scrutinise transactions which actually benefited the creditors as a whole - a conclusion which may be reached when considering the commercial realities and the actual economic effect of the transaction. ${ }^{41}$

35 Insolvency Guide (supra note 13), Part Two, Ch. II, Paras. 174-76.

36 As mentioned above, the goal is to ensure equitable treatment of creditors and to address the problem of managerial (and creditors') perverse incentives near insolvency (see supra notes 4-12 and accompanying texts).

37 Insolvency Guide (supra note 13), Part Two, Ch. II, Paras. 175.

38 See also Baird, Legal Approaches (supra note 9), 203, and the approach of the British court in Phillips v Brewin Dolphin Bell Lawrie Ltd [2001] 1 All ER 673 (the House of Lords emphasised the need to consider the transaction as a whole, and thus consideration provided by a subsidiary of the debtor was also taken into account).

39 The laws of England and Wales, for example, require that the debtor should have entered into the transaction under influence by a desire to favour the person receiving the preference (see s. 239(5) of the Insolvency Act 1986). Compare with the U.S. approach which does not require proof of intent but includes numerous exceptions (US Code, Title 11, s.547).

40 Insolvency Guide (supra note 13), Part Two, Ch. II, Paras. 177-79.

41 See, e.g., the Australian case Airservices Australia v Ferrier (1996) 137 ALR 609 (where 
With respect to all avoidable transactions there are usually stricter criteria when "related persons" (sometimes also referred to as connected persons or insiders) are involved. ${ }^{42}$ As mentioned above, the relationship between the company and the other party to the transaction may be a relevant indicator of fraud. ${ }^{43}$ In the context of preferences and transactions below value, the suspect period will typically be longer where related persons where party to the transaction or presumptions (or shifted burden of proof) regarding intent or the financial situation of the company may be applied. ${ }^{44}$ Indeed, perverse incentives to shift assets or enrich certain third parties may be most pronounced with regard to associated parties. ${ }^{45}$ Contracts with connected persons may not be negotiated in the market place and so one may not assume that the company received a fair deal. ${ }^{46}$

Based on these common denominators, but further as a measure for modernising and renovating insolvency laws, ${ }^{47}$ the Insolvency Guide ${ }^{48}$ provides a list of recommendations on avoidance provisions which now represent a consensus regarding best practises in this respect. It is suggested to include powers to avoid in regard to the three typical avoidable transactions (fraud, undervalued transactions and preferences) in insolvency laws. ${ }^{49}$ Crucially, the elements of avoidance that need to be proven and any possible defences should be specified in the law. In this regard, it is proposed that the usual defence would be that the transaction was entered into in the ordinary course of business. It is also proposed that the law may establish presumptions and permit shifts in the burden of proof to facilitate the conduct of the proceedings. Furthermore, the law should specify the suspect period, calculated retrospectively from the date

in a situation of continuous trading the court concluded that the payment to a creditor actually benefited the company since it induced the creditor to supply goods of equal or greater value than the amount of the payment).

42 Insolvency Guide (supra note 13), Part Two, Ch. II, Para. 182.

43 Supra note 32 and accompanying text.

44 Insolvency Guide (supra note 13), Part Two, Ch. II, Para. 182. For example, under the laws of England and Wales the desire to favour a person receiving a preference is presumed when the person is connected to the company (s. 239(6) of the Insolvency Act 1986). It is also presumed that the company was insolvent at the time of entry into an undervalued transaction (or became insolvent by virtue of entry into the transaction) when a transaction with a connected person is in question (s. 240(2)(b) of the Insolvency Act 1986).

45 See Mokal, Corporate Insolvency (supra note 6), 307.

46 See Baird, Legal Approaches (supra note 9), 210-11.

47 See Block-Lieb and Halliday, Harmonization (supra note 24), 476-77 and 488-98 (observing that the Guide intends to improve legal systems not only converge them).

48 Supra note 13.

49 See Recommendation 87 of the Insolvency Guide (ibid.). It also suggests that security interests may also be attacked as avoidable (Recommendation 88). 
of the application for or the commencement of insolvency proceedings, within which a transaction may be avoided..$^{50}$ In this respect, the Insolvency Guide suggests that the law may specify that the suspect period for avoidable transactions involving related persons (which should include persons in a position to control the debtor and a parent, subsidiary or affiliate of the debtor) is longer than for transactions with unrelated persons. ${ }^{51}$ To sum it up, avoidance provisions started with combating fraud and were extended to other forms of harm to creditors (especially in the vicinity of insolvency), where the basic idea is to ensure equitable treatment to creditors while preserving the legal effects of beneficial transactions. This requires focusing on substance rather than legal form - evaluating the true economic effect of a transaction or a set of transactions. As has been observed, this makes the law potent but also somewhat unpredictable..$^{52}$ The task of attacking vulnerable transactions has intensified with transactions becoming more complex and sophisticated,,$^{53}$ and may reach its peak in complex business structures such as groups (with multinational groups adding yet another complexity). Within this business form, transactions may be numerous and more compound, and may typically involve parties associated with one another.

\section{Addressing the Group Problem}

\section{A. Legal Form Versus Economic Realities}

The gist of avoidance provisions is now clear, yet the question is how these should be applied in a group context, i.e. where transactions have been conducted between group members or in regard to creditors of affiliate companies. Should such transactions be addressed on an entity-by-entity basis, namely with no regard to the group situation, or should economic realities lead the way to determine whether to avoid or uphold any such transaction, ignoring legal form to a certain extent. This section will briefly consider the general tension between entity law and enterprise principles (the two alternative doctrines for regulating groups) before moving on (in the subsequent section) to address avoidance provisions in the group context.

Traditional "entity law" suggests applying the fundamental corporate law concepts of corporate personality and limited liability in the group context. Thus, the distinct corporate personality of each group member and the limited liability of the parent and each affiliate vis-a-vis the other group members shall

50 Recommendations 89 and 97 of the Insolvency Guide (ibid.).

51 Recommendation 90 and Introduction, Para. 12 (jj) of the Insolvency Guide (ibid.).

52 Baird, Legal Approaches (supra note 9), 214.

53 Ibid. 
be upheld. In contrast, modern "enterprise law" suggests that, at least under certain circumstances, the enterprise should be regarded as the relevant entity and that effect should be given to the relationship among the group members. ${ }^{54}$ Enterprise principles are thus concerned with matching rights and responsibilities to the collective economic activity, i.e. to the enterprise comprised of separate but related companies. ${ }^{55}$ Arguably, this reflects current economic realities better where enterprises operate unified businesses as groups. Consequently, a "new" entity is recognised, redefining the legal boundaries of the business organisation to some extent so as to suit economic realities. ${ }^{56}$

I have suggested elsewhere that whether enterprise law should supersede entity law should depend on the degree to which a legal device based on enterprise principles actually interferes with the notion of limited liability. Where it does not, there should be little problem to give effect to the connections between group members. ${ }^{57}$ The starting position should then be the economic reality where the group may represent something unique - different from the mere sum of its parts. ${ }^{58}$ Effect should be given to this reality if this fulfils the objectives of the relevant area of the law. ${ }^{59}$ For example, it is desirable that groups prepare consolidated annual reports. This will not come into conflict with limited liability and will give a true and fair view of the financial situation of the group members.

Only when limited liability is at stake, greater caution is required as it may contravene efficiency advantages underlying the rationale for limited liability. Thus, because each group member is liable for its debts and assets are segregated within each entity, creditors do not need to monitor the creditworthiness of other group members when they extend credit to a particular entity (thus saving transaction costs).$^{60}$ Interference with limited liability should be the exception

54 PI Blumberg, The Corporate Entity in an Era of Multinational Corporations 15 Del. J. Corp. L. 283 (1990); CM Schmitthoff, The Wholly Owned and the Controlled Subsidiary Journal of Business Law, 218, 219-222 (1978).

55 Blumberg, The Multinational Challenge (supra note 2), at 245.

56 AA Berle Jr, The theory of enterprise entity 47 Colum L Rev 343, 348-350 (1947); Blumberg, The Multinational Challenge, supra note 2, at 232-233.

57 See Mevorach, Enterprise Groups (supra note 21), 47-49.

58 Id.

59 See P.I. Blumberg, "The Transformation of Modern Corporation Law: The Law of Corporate Groups” (2005) 37 Conn. L. Rev. 605, 611; R.B. Thompson, "Piercing the veil within corporate groups: corporate shareholders as mere investors” (1999) 13 Conn. J. Int'l L. 379, 396.

60 On the benefits of 'asset partitioning' see H. Hansmann and R. Kraakman, “The Essential Role of Organizational Law” (2000) 110 Yale L.J. 387. See further on limited liability in the group context Mevorach, Enterprise Groups (supra note 21), 41-49. 
rather than the rule, and here enterprise law should have a modest role-assisting to shape the exceptions to limited liability in the group context. ${ }^{61}$ How then should enterprise law apply in the context of avoidance provisions?

\section{B. Adjusting the Usual Avoiding Provisions to Accommodate Corporate Groups}

\section{B.1 The Effect of Enterprise Law in the Transaction Avoidance Context}

What is, first, crucial to enquire is whether enterprise law, applied to transaction avoidance provisions, would threaten limited liability in any way. As concluded above, if this may be the result then much more caution is required. The answer to this question depends on the way enterprise law would apply in this context. If the application of enterprise law would mean that any transaction between entities of a corporate group would be regarded as a transaction between divisions of a single entity (that is the group), then the effect of enterprise law is indeed significant and harmful to the economic rationale of limited liability. It means a mix of assets and liabilities, ignoring the asset partitioning between the entities. If, however, enterprise law only assists in determining whether a transaction should be upheld or avoided, allowing to investigate the benefit to the company in question while appreciating the bigger picture of the group situation and the inter-relations among the group members, then there is not much at stake. The assets and debts of the different entities are not being mixed, liability for the debts of any member is not imposed on another member, debts are not generally and across-the-board re-characterised, eliminated, subordinated and so forth. Rather, only a particular transaction may be reversed, and only the creditors of the relevant entity (involved in the transaction) are affected to the extent that they have benefited from a transaction outside the terms of the original bargain (because the transaction was preferential, fraudulent, undervalued and so forth). Applied in this way, enterprise law should be 'welcomed' (when addressing transaction avoidance provisions) and utilised with little hesitation and no further justification where it can enhance the aims of the area of the law (and have some added value with reference to entity law) - in this case, the goals of insolvency law.

Indeed, enterprise law can shed important light on vulnerable transactions involving enterprise groups. As concluded above, to achieve a fair and efficient insolvency system a balance should be struck between the finality of transactions and the protection of creditors from harmful transactions taking place in the vicinity of bankruptcy (or from any fraudulent transfers). In this respect, 
substance should prevail over form - revealing the true economic effect of the transaction. Here, enterprise law can certainly assist as it can allow a better understanding of the true nature of the transaction and the commercial reality surrounding it. In particular, it can ensure that the diversified scene of group structures and organisational patterns is taken into account. Groups come about in different shapes - some closely integrated, some true conglomerates with no significant links between the members ${ }^{62}$ - and therefore a "one size fits all" approach to how transactions should be treated in this context is not appropriate. The phenomenon of groups requires a nuanced approach to its regulation. Pure entity law which would consider each group member on a completely separate basis might ignore these nuances (and thus the effect of the type of group at hand on the legitimacy of the transaction), defeating the law's objectives. This concept will be further explored below while investigating UNCITRAL's new recommendations on avoidance powers (in the context of the insolvency of enterprise groups). Specifically, it will be explored whether the recommendations fall within the ambit of the desirable balance between entity and enterprise law as delineated above.

\section{B.2 Assessing the New Recommendations (of UNCITRAL) on Avoidance and Groups}

UNCITRAL's new recommendations regarding avoidance provisions in the group context ${ }^{63}$ commence with a "purpose clause". The clause seems to generally appreciate the concept of applying enterprise law in the context of the existing avoidance provisions. It does not suggest, though, any acrossthe-board elimination of transactions ignoring the separation between the group entities. Indeed, that would not be desirable. Thus, the clause suggests that:

"The purpose of avoidance provisions as among enterprise group members is to provide, in addition to the considerations set forth in recommendations $87-99$, that the insolvency law may:

(a) Permit the court to take into account that the transaction took place in the context of an enterprise group and

(b) Establish the circumstances that may be considered by the court." 64

Specific considerations may be taken into account when applying the usual transaction avoidance provisions (on which the Insolvency Guide already

62 See Blumberg, The Multinational Challenge, (supra note 2), 144-47. See also Mevorach, Enterprise Groups (supra note 21), 130-33.

63 Which will be included in Part III of the Insolvency Guide (see supra note 19).

64 Part III of the Guide (ibid.), Recommendations 217-218, Purpose of Legislative Provisions. 
provides recommendations ${ }^{65}$ ) in a group context. But what sort of considerations? Would the enterprise approach imply harsher scrutiny of transactions involving group members, or rather the other way round? The recommendations provide that in considering vulnerable transactions in the group context courts may take into account the circumstances in which the transaction took place, and those circumstances may include:

"... the relationship between the parties to the transaction; the degree of integration between enterprise group members that are parties to the transaction; the purpose of the transaction; whether the transaction contributed to the operations of the group as a whole; and whether the transaction granted advantages to enterprise group members or other related persons that would not normally be granted between unrelated parties. "66

The recommendation refers to a host of considerations of circumstances and does not limit itself to either avoidance or legitimisation of transactions. The enterprise lookout over the transaction may thus lead to either avoiding a transaction that might not have been avoided if conducted in a single company context or upholding a transaction that would otherwise have been avoided if not entered into in a group context.

Consider firstly the reversal of transactions based on group considerations (which is one possible outcome of giving effect to group interrelationship). In fact, the concept of considering transactions between related persons as suspect is not new. It was mentioned above that it is common to subject transactions between related persons (which usually include group members) to particular scrutiny, and thus apply longer twilight periods or presumptions against the validity of the transactions. ${ }^{67}$ Indeed, the risk of opportunistic behaviour (including harming creditors by entering into transactions) is considerable in the context of groups. Particularly, if the enterprise operated a single business or there were other significant administrative or financial links between the entities ${ }^{68}$ (making it an 'integrated group'), controllers and other affiliates may be in a position to be knowledgeable about the financial situation of other group members, typically before it is revealed to outsiders. Under such circumstances, group controllers may attempt to shift assets from a distressed entity to other entities within the group, making sure that the

65 Recommendations 87-99 of the Insolvency Guide (supra note 13).

66 Part III of the Guide (supra note 19), Recommendation 217. Recommendation 218 further provides that the insolvency law should specify the manner in which the elements to be proven to avoid a particular transaction and defences to avoidance would apply in the group context.

67 See supra notes 42-46 and 51 and accompanying texts.

68 See Mevorach, Enterprise Groups (supra note 21), 132-4. See also PT Muchlinski, Multinational Enterprises and the Law (Oxford University Press, Oxford 2007), 48. If the group was integrated even to the extent that assets and debts were intermingled, other remedies may be more adequate (see infra Part II(C)). 
assets will not be distributed to the creditors of the distressed entity, but rather utilised by other members of the group. ${ }^{69}$ In an international setting (where the group is multinational), opportunities for abuse are even greater, as for instance, assets may be transferred to remote jurisdictions. ${ }^{70}$

But the main novelty in the recommendation is certainly the latter aspect of the approach, namely the possibility that a transaction may be regarded legitimate (and be upheld) by taking a broad group-wide perspective, even if entered into in the vicinity of bankruptcy and could have been perceived as undervalued or preferential to a creditor if seen on a separate-entity basis. More generally, it is the concept that the transaction should be considered in a broad group context which may result in either its reversal or its maintaining. Thus far, legal regimes have tended to take an entity approach and apply the normal requirements under avoidance provisions when considering whether to uphold intra-group transactions. ${ }^{71}$ At the least, an enterprise approach is not readily apparent in avoidance transactions' provisions, apart from the idea to treat transactions with related persons with greater scrutiny. Yet, transactions between group members, even (and in many cases especially) on the brink of bankruptcy, may make sense from a commercial perspective, particularly because they took place within a group of entities. ${ }^{72}$ Such transactions could be attacked as preferential or as depleting an affiliate's assets if taking place among 'strangers'. This, again, is particularly relevant when considering the integrated groups. ${ }^{73}$ Considering the economic reality of a group being a single business and/or having significant connections between the entities may sug-

69 It should be noted that two group members that are parties to an asset transfer may, among themselves, be non-integrated, e.g. operating in two different industries, yet they may have a mutual controller to which each of the entities is closely related and which may have initiated the vulnerable transaction. See, for example, the allegations regarding diversions of funds between the two different businesses controlled by the Tanzi family that controlled the Parmalat group (which collapsed in 2003). According to statements of Parmalat's officers during interrogations, funds were diverted from Parmalat Finanziaria SpA to Parmatour, the controlling family's tourism business (see The Associated Press, "Ex - Parmalat CFO Reportedly Blames Tanzi”, New York Times, October 3, 2004).

70 See Mevorach, Enterprise Groups (supra note 21), 286. See also Part III of the Guide (supra note 19), Paras. 77-78.

71 See Blumberg et al, Blumberg on Corporate Groups (Aspen Publishers, 2005), Vol 2, s. 85.05[A] [hereinafter: Blumberg, Blumberg on Corporate Groups], at vol 2, s. 85.19[a]; A Muscat, The Liability of the Holding Company for the Debts of its Insolvent Subsidiary (Dartmouth Publishing Group, Aldershot 1996), 232 [hereinafter: Muscat, The Liabil$i t y$ ], at. 228). Though, occasionally, indirect benefit to a group member from the support it provides to other members of the group may be acknowledged when considering what 'fair consideration' is (ibid).

72 See Part III of the Guide (supra note 19), Para. 79.

73 Supra note 68 and accompanying text. 
gest a different allocation of benefits and detriments (or estimation of a preferential position), compared to the consideration of the transaction which is based on a separate-entity perspective. In particular, an enterprise-wide approach may show that there was a group interest in entering into the transaction which may have also benefited the entity that is party to it.

Consider, for example, a transaction where one affiliate gives a guarantee or security to the lender of another group member for the purpose of allowing the latter to raise further funds crucial to the continuance of its business. Between unrelated parties, the transaction may seem unfavourable to the guarantor. Under certain circumstances, it may seem as a pure gift with no consideration if the guarantor does not receive any fee or anything tangible in return. However, considering the integration between these two entities may lead to the conclusion that the company guaranteeing the debt may have been dependent on the other affiliate to an extent (e.g., in terms of supply of products or services). Therefore, it would have benefited from ensuring that the affiliate keeps operating. Generally, a guarantor entity in an integrated group may have a true commercial interest in strengthening the financial position and the business of other group members, being as it is part of a single enterprise. ${ }^{74}$ In case it appears that the guarantor had indeed some benefit from giving the guarantee (when considered on a group-wide basis), extra care should be applied when considering to reverse the transaction to the detriment of the entity in favour of which the guarantee was given to the lender. Indeed, in a group scenario it may well be that intra-group guarantees as described above are the only way to secure any credit for the distressed affiliate and gain breathing-space for the group as a whole.

Similar considerations may take place in regard to transactions which may seem preferential. The insolvent affiliate may have paid an antecedent debt to a related company rather shortly before entering into insolvency, i.e. within the suspect period. Happening between the debtor and an external creditor, this may be regarded as preferring the latter. It may seem even more suspicious as it was paid to a related company with knowledge of the financial situation of the affiliate in issue. Yet, considering the transaction in the broad group context, an investigation of the nature of the group may reveal that there was commercial sense in the transaction. Specifically if the parties to the transaction belonged to an integrated group of the sort that runs a single business, it might have been crucial to the continuance of the business of the (now) insolvent affiliate to pay its related company because of the inter-dependence of the group members (if, e.g., the group was in the process of closing a major deal). In other words, at the time of entry into the transaction, taking an enterprise

74 See also Blumberg, Blumberg on Corporate Groups (supra note 71), at Vol 2, s. 85.05[A]; Muscat, The Liability (supra note 71), 232. 
approach may reveal that the benefit to the general body of creditors (of that affiliate), accrued from the payment in question, was greater than the amount of the payment itself. ${ }^{75}$

In summary, consideration of the various circumstances which UNCITRAL recommendations refer to is indeed crucial to the design of a desirable approach to transaction avoidance in the group context, ultimately enhancing a fair and efficient bankruptcy system. The essence of those considerations seems to be to take a group-wide perspective on the transaction which involved group members, emphasising substance over form and enquiring whether there was a group explanation (or otherwise group suspicion) regarding the transaction. The degree of integration of the group members is a key factor, just as well as the relations between the members and the way the group has been managed. In case of integration and close connections, presumptions against the related company are stronger. Yet, taking such a group-wide perspective may, at the same time, actually mean upholding a transaction. In no event, though, do the recommendations suggest to ignore the corporate form and treat the group members as belonging to a single entity. All in all, they strike a desirable balance between entity law and enterprise law.

\section{Avoidance Provisions versus Other Solutions for Group Bankruptcies}

It was mentioned above that there may be particular circumstances related to the group operations which could justify more dramatic remedies in terms of their interference with the corporate form. Indeed, the new recommendations of UNCITRAL for the insolvency of groups include additional solutions and remedies, some of which are quite interventionist, others more procedural. It is important to appreciate the relationship between these solutions and the avoidance provisions and ascertain under which circumstances each would be more adequate and what the role of each solution is.

Substantive remedies include the recommendation regarding substantive consolidation, ${ }^{76}$ and further commentary regarding subordination and extension of liability. ${ }^{77}$ The question is which remedy shall be applicable - avoidance of transactions or any of the other remedies - in situations of misbehaviour in regard to transactions involving group members detrimental to the creditors.

The framework discussed above for resolving the group problem hints at the answer. As aforementioned, we should be particularly cautious not to ruin the

75 Cf. Airservices Australia v Ferrier, mentioned above (supra note 41).

76 Part III of the Guide (supra note 19), Recommendations 219-231.

77 Ibid., Paras. 83-104. 
benefits of limited liability and asset-partitioning when applying enterprise principles. ${ }^{78}$ In this light, applying avoidance provisions to tackle intra-group transactions and misbehaviour in the group context would usually be the better option compared to the other more interventionist remedies. As mentioned above, applying enterprise law to avoiding transactions (in the way suggested above) may pose less threat to limited liability. ${ }^{79}$ Extending liability, on the other hand, would make one member - the member responsible for the detrimental transactions - generally liable for the debts of the subsidiary, which stands in clear conflict with the limited liability concept. Substantive consolidation (the pooling of assets and debts in the course of insolvency, which usually includes the elimination of intra-group transactions $\left.\mathrm{s}^{80}\right) \mathrm{com}-$ pletely ignores the separation between the members of the group (even though the competition takes place between the creditors of the different members and not an entity and its shareholders ${ }^{81}$ ), thus interfering with the benefits of assets-partitioning. ${ }^{82}$ Similarly, subordination of intra-group claims to the claims of the insolvent group member's external creditors involves competition among creditors (rather than a mere imposition of liability upon a shareholder), ${ }^{83}$ yet, here too, the benefits of 'asset-partitioning' are at stake. The prospect of equitable subordination of intra-group debts increases the risk of non-payment to the subordinated party and therefore induces the creditors of that company to investigate the other affiliates' creditworthiness. ${ }^{84}$ Ultimately, subordination serves a similar function as veil-piercing since if the claims of a related company are subordinated, the creditors of the insolvent affiliate will be satisfied from assets that would otherwise serve to partially satisfy the claims of the related company. ${ }^{85}$ Therefore, all these other remedies proposed or discussed by UNCITRAL should be applied only when avoidance provisions are not adequate (or cannot tackle the misbehaviour) under specific circumstances.

78 See supra Part III(A).

79 See supra Part III(B).

80 See e.g. pooling orders under the New Zealand Companies Act 1993, ss. 271-272, and substantive consolidation orders based on 11 USC, s. 105 (2000).

81 J Landers, "A Unified Approach to Parent, subsidiary and Affiliated Questions in Bankruptcy” (1975) 42 U Chi L Rev 589, 634 (arguing that the doctrine of limited liability is not involved in the issue of consolidation) [hereinafter: Landers, A Unified Approach].

82 Unless substantive consolidation is applied by consent (creditors should be able to waive their 'asset partitioning' benefit).

83 Landers, A Unified Approach (supra note 81), 634.

84 Though the potential liability under the subordination regime of the parent is limited to the amount of the loan, whereas imposing general liability may amount to the entire subsidiary's debts (see R Posner, “The Legal Rights of Creditors of Affiliated corporations: An Economic Approach” (1976) 43 U Chi L Rev 499, 517-19).

85 Blumberg, Blumberg on Corporate Groups (supra note 71), s.87.01. 
One such scenario is where the group is so heavily integrated that its assets are intermingled in the ordinary course of business. ${ }^{86}$ Under these circumstances, transferring assets among the entities might have taken place excessively and even without record-keeping as if this was not a transaction between separate entities, but rather an allocation of assets among 'departments' of the same entity. If this occurred, it might be impossible or extremely difficult to detect the actual transactions that took place among the group members and which entity owns an asset or which entity's assets were depleted as a result of the intra-group transactions. Untangling the transactions will be either impossible or disproportionally costly. Eliminating the transactions by a pooling order will be the most adequate solution. It represents a rare exception to limited liability where asset-partitioning was only a 'façade' and is therefore not really defeated by substantive consolidation. ${ }^{87}$ Under these particular circumstances, pooling will benefit the creditors (by making the process much more efficient) and will not harm asset-separation as this concept was not kept by the types of groups which were excessively entangled.

The recommendations of UNCITRAL on substantive consolidation seem to appreciate their 'intrusive nature'. They provide that substantive consolidation should be applied only under exceptional circumstances of intermingling of assets and debts, ${ }^{88}$ or where the court is convinced that enterprise group members were engaged in a fraudulent scheme or activity with no legitimate business purpose (and only where substantive consolidation is essential to rectify that scheme or activity). ${ }^{89}$

There are no new recommendations provided on subordination and extension of liability, only commentary reflecting the discussion of the issue by the working group of UNCITRAL and various possible ways to address the matter. This is to be regretted as concrete recommendations would have shed light, not only on the international standard regarding these remedies (enhancing certainty in this area), but also on their relationship to substantive consolidation and avoidance provisions. ${ }^{90}$ In any event, in light of the discussion above, it seems that subordination and extension of liability should be "weap-

86 See Mevorach, Enterprise Groups (supra note 21), 132, 290.

87 Ibid., at 225. Transactions between group members and external creditors are not eliminated but may be tackled by the representative of the pooled estate. The proposals suggest that the date from which the suspect period should be calculated under such circumstances may be either different for each group member or a common date for all members included in the substantive consolidation (Part III of the Guide (supra note 19), Recommendation 228).

88 Ibid., Recommendations 220(a).

89 Ibid., Recommendation 220(b).

90 See also I Mevorach, "Is the Future Bright for Enterprise Groups in Insolvency? Analysis of UNCITRAL's New Recommendations on the Domestic Aspects”, in In- 
ons" of last resort to be applied only when there is proof of wrongful or fraudulent conduct and the misbehaviour cannot be linked to specific transactions (e.g. one which defrauded creditors), or where such transactions do not fulfil the specific criteria of the avoiding powers (because, for example, they did not take place within the suspect period). ${ }^{91}$

The new recommendations further attempt to facilitate the provision of finances by enterprise group members, including group members subject to insolvency proceedings. They recommend that the insolvency law permit intragroup financing (including grants of securities or guarantees to other lenders providing the finance) after the commencement of insolvency proceedings ("post commencement financing") and specify the priority that applies to such financing. It should be taken into account whether such finance is necessary for the continued operations, survival, preservation or enhancement of the receiving group member's business value. And in case creditors seemed to be harmed, it should also be considered whether this will be balanced by the benefit to be derived from the financial advancement (or grant of a security, guarantee or other assurance) which may eventually lead to a better result for the group as a whole. ${ }^{92}$ In this regard, an approach similar to the one taken in regard to avoidance provisions is taken, where enterprise law is central and a group-wide perspective is utilised. Indeed, limited liability is not at stake, but rather it is considered whether a specific loan transaction was in fact beneficial to the group member, viewed from a wider group perspective.

Finally, the new proposals contain procedural solutions for group bankruptcies, key among which is the concept of procedural coordination. This permits proceedings against two or more group members to be handled coordinately, if possible before the same court and with the same insolvency representative. ${ }^{93}$ This does not imply any substantive remedy. Rather, the idea is to facilitate group-wide efficient solutions and to minimise costs by avoiding duplication of effort and facilitating the transfer of information, valuation of assets and identification of creditors. ${ }^{94}$ Such coordination and centralisation of proceedings can also facilitate the handling of past manipulations - including vulnerable transactions - as it will make it easier to appreciate the broader group context and obtain the necessary information which can shed light on the

ternational Insolvency Law: Reforms and Challenges 371, 391 (P.J. Omar ed., forthcoming 2011).

91 A discussion of the question- when exactly liability should be imposed is beyond the scope of this paper (see on this issue Mevorach, Enterprise Groups (supra note 21), 294310).

92 Part III of the Guide (supra note 19), Recommendations 211-216, and Para. 63.

93 There may be varying degrees of coordination (see Part III of the Guide, ibid., Recommendations 202-210, 232-236).

94 Ibid., Para. 22. 
transaction as a whole. At the same time, though, problems of conflict of interests should be tackled as the avoidance of transactions could benefit one member and be detrimental to another. In case it seems necessary, additional representatives may be appointed. ${ }^{95}$

\section{A Comment on International Complexities}

Vulnerable transactions involving international groups present additional difficulties. Although this paper has emphasised the similarities between legal systems regarding voidable transactions, a harmonisation of insolvency laws in general and avoiding powers in particular has as yet not been achieved. ${ }^{96}$ Certainly, the application of these provisions to the group scenario in different legal systems is not readily ascertainable, as mentioned above. Undoubtedly, differences between legal systems make it a difficult task to design a crossborder transaction and to ensure it will not be derogated by any laws which may have relevance to the company (which had cross-border business). ${ }^{97} E x$ post (in the course of insolvency), the international scenario could result in difficulties to tackle past manipulations (as well as to defend them) where problems of recognition and enforcement of judgements may arise. Moreover, taking a group perspective may be unrealistic where the group is spread among different jurisdictions and information is not within reach.

Further harmonisation and convergence of avoiding powers (including their application in the group context) is thus crucial. Certainty of the similarity of applicable insolvency rules in regard to a transaction will enhance legal predictability, even if is the transaction takes place between parties situated in different jurisdictions. Similar insolvency rules will also increase the likelihood of smooth and fast recognition and enforcement of relevant judgements. ${ }^{98}$ Especially in the group context, this may be crucial, as legal regimes tend to be protective of the notions of corporate separate personality and limited liability. If a foreign system is perceived as too intrusive to these legal

95 Ibid., Recommendation 233.

96 There are, for example, variations in regard to the duration of the suspect period, or the need to prove intent to prefer a creditor.

97 Perry, Transaction Avoidance (supra note 32), 46.

98 See e.g. the case of Rubin (Rubin v Eurofinance and Others CA 30 July 2010) where the English Court of Appeal concluded that a judgement of a New York court avoiding a transaction should be enforceable in the UK without the need for a separate process to be opened, noting the similarities between the avoidance provisions under English Law and under American law (ibid., Para. 60). See also the report prepared by INSOL Europe (commissioned by the European Parliament (European Parliament Report: Harmonization of Insolvency Law (26 April, 2010), Para. VIII recommending harmonisation of avoidance powers within Europe. 
institutions, there may be great difficulties in terms of recognition and enforcement of judgements rendering transactions void.

Harmonisation of the private-international-law aspects can further assist in overcoming the above-mentioned problems. This is particularly true for a uniform jurisdictional rule which could direct all proceedings against group members to a single jurisdiction (or allow the identification of a coordinating forum), referring to this jurisdictions' insolvency law in regard to the application of avoiding powers and enforcing its judgements. This way, information about the intra-group transactions may be more readily ascertained, a single court could consider all relevant circumstances relevant to the intragroup transactions and its decisions could then be recognised and enforced in the other jurisdictions involved.

This might be achieved under current frameworks for cross-border insolvency if a single centre of main interests (COMI) is identified for all relevant group members, and if the principal court's judgements are recognised and enforced elsewhere. Under both the EC Regulation on Insolvency Proceedings ("EC Regulation)" and the Model Law on Cross-Border Insolvency ("Model Law"), ${ }^{100}$ main proceedings are to be recognised if they were opened at the company's COMI. ${ }^{101}$ Furthermore, the European Court of Justice has established the notion that avoidance issues are matters directly related to the insolvency of a company and thus subject to the exclusive jurisdiction of the country in which main proceedings have commenced. ${ }^{102} \mathrm{~A}$ similar approach may be embraced by countries adopting the Model Law ${ }^{103}$ or by applying national private-international-law rules of insolvency. ${ }^{104}$

The problem is that considering the COMI of each group member separately

99 Council Regulation 1346/2000, Insolvency Proceedings, 2000 O.J. (L160) (EC).

100 U.N. Comm'n on Int'L Trade Law [UNCITRAL], UNCITRAL Model Law on Cross-Border Insolvency with Guide to Enactment, U.N. Sales No. E.99.V.3 (2000).

101 Article 3(1) and 16 of the EC Regulation (supra note 99); Article 2(b) and 17(2)(a) of the Model Law (supra note 100).

102 Seagon v Deko Marty Belgium NV (c-339/07) [2009] 1 WLR 2168.

103 See Rubin (supra note 98) where the English Court of Appeal confirmed that recognition of the avoidance actions which took place in the course of the US bankruptcy proceedings should be granted as these proceedings were part and parcel of the main bankruptcy proceedings against the debtor. It then also concluded that the judgement should be enforced in the UK without the need to open separate proceedings. Although this decision was based on common-law principles of assistance (noting that the main principle in private international law of insolvency is that of universality and unity), the court did express the view that a similar result may be achieved under the Model Law's provisions on cooperation (ibid., Para. 63).

104 Ibid. 
may result in multiple proceedings (especially if the identification of the COMI heavily relies on the place of the registered office of each company ${ }^{105}$ ), rather than in a unitary insolvency process which could receive worldwide recognition and consequently apply universally to all the group's assets. Still, if the proceedings against each group member are recognised and judgements are mutually enforced, the problem is mitigated. However, such multiple claims and recognition proceedings could significantly increase the costs and the likelihood of success in challenging voidable transactions. This can be overcome by a coordination of the multiple processes, also in regard to the avoidance powers (as suggested by UNCITRAL's new recommendations on the international aspects of enterprise groups' insolvencies $\left.{ }^{106}\right)$. The adoption of pre-defined rules regarding the centralisation or coordination (from a single forum) of group proceedings, embracing a jurisdictional rule which identifies the centre of the group as a whole would be even better. ${ }^{107}$

With regard to choice of law of avoiding powers, current rules are quite uncertain and different options can be found in national and international regimes. Under the EC Regulation, ${ }^{108}$ for example, avoidance provisions are subject to the law of the forum unless the other party to the transaction with the debtor can defend the transaction, showing that it is valid and unimpeachable according to the law by which it is properly governed. The Model Law ${ }^{109}$ does not provide uniform choice-of-law rules. Although, under the Model Law, a foreign insolvency representative may seek remedies aimed at illegitimate antecedent transactions in the jurisdiction which has granted recognition to the foreign proceedings - this does not create substantive rights or determine the choice-of-law rule. ${ }^{110}$ Further predictability, efficiency and fairness in the handling of group bankruptcies including the resolution of past manipulations could be promoted by the adoption of a universalistic uniform choice-of-law rule. Such a rule would refer to the main forum's law rather than to the territory in which the transaction occurred (or to any other case-specific

105 Rather than to focus on the actual head-office which will usually allow the identification of a single forum for all group members in an integrated-centralised group scenario (see I. Mevorach, “The Home Country of a Multinational Enterprise Group Facing Insolvency" (2008) 57 International and Comparative Law Quarterly 427).

106 Part III of the Guide (supra note 19), Para. 236(c).

107 UNCITRAL working group has attempted to develop an 'enterprise group COMI' concept (identifying the centre of main proceedings of a group for the purpose of international jurisdiction in insolvency), yet a consensus on this has not been reached (see I. Mevorach, "Towards a Consensus on the Treatment of Multinational Enterprise Groups in Insolvency” (2010) 18 Cardozo J. of Int'l \& Comp. L. 359, 389-414).

108 Article 13 of the EC Regulation (supra note 99).

109 Supra note 100.

110 Article 23 of the Model Law (ibid.). See also Fletcher, Insolvency (supra note 17), at 471. 
choice-of-law rules based on contacts and state interests presented in each case). ${ }^{111}$ Indeed, the Insolvency Guide (in its original parts, in regard to single debtors) proposes that insolvency proceedings shall be governed by the law of the forum (the lex fori concursus) with limited exceptions. Specifically, it proposes that the insolvency law of the state in which insolvency proceedings have commenced may apply to vulnerable transactions. ${ }^{112}$

\section{$V$ Conclusion}

Avoidance provisions have a role to play in promoting bankruptcy goals in the context of corporate groups' default. A corporate group is not a corporate body as such and so in general, intra-group transactions do not take place between 'departments' of the same entity, but rather between separate legal entities. Therefore, they may be vulnerable and avoided in the context of bankruptcy. In fact, transactions between group members may be particularly suspect considering the possible close relationship and prior knowledge group entities may have on one another. At the same time, though, these transactions may make sense commercially when considering the broad context of group operations and group interest. Enterprise law should guide the way in which vulnerable transactions are scrutinised where groups are involved, yet its role should be limited to the confinements of avoiding specific transactions. The result cannot be to break the walls separating the legal entities, unless there are specific justifications for this. In that case, other remedies, such as substantive consolidation or subordination, should come into play. The new recommendations of UNCITRAL on avoidance provisions involving enterprise groups seem to go along such lines. Thus, they strike an adequate balance between entity law and enterprise law. Their implementation in legal systems would certainly advance the goals of insolvency - promoting fair and efficient insolvency laws. Their wide adoption (which could result in a degree of harmonisation in this area) would also serve the goal of advancing an effective crossborder insolvency system, specifically in regard to the treatment of international groups in default. Ex ante efficiency would be promoted where the rules

111 Especially considering that following the application of avoiding powers, the debtor's assets are redistributed according to a set of priority rules which are also to be determined by the forum's court and laws (see JL Westbrook, "Choice of Avoidance Law in Global Insolvencies” (1991) 17 Brook J Int'l L 499, 530; Westbrook, Avoidance (supra note 25), 902-04). See also the case of Condor Insurance where the US appellate court concluded that avoidance relief under the foreign law (of the foreign main forum) can be granted under Chapter 15 (the US Model Law version) (In re Condor Insurance Limited, Fogarty v Petroquest Resources Inc. 601 F.3d 319, 2010 WL 961613 (5 $5^{\text {th }}$ Cir. 2010).

112 Insolvency Guide (supra note 13), Part two, Ch. I, Recommendation 31 (g). 
are more readily ascertained. Furthermore, greater similarity between the laws could facilitate mutual recognition and enforcement of judgements, as well as the deference to foreign forums which would then be able to comprehensively and effectively handle all insolvency matters concerning the enterprise group. 